\title{
Proceeding
}

Supplementary Issue: Summer Conferences of Sports Science. Costa Blanca Sports Science Events, 25-26 September 2020. Alicante, Spain.

\section{Swimming, back pain and electromyography: A brief review}

\author{
CRISTIANA D'ANNA , AURORA D'ALESSANDRO, RODOLFO VASTOLA \\ Department of Human, Philosophical and Educational Sciences, University of Salerno, Italy
}

\begin{abstract}
Background: The low back is the most common site of pain in the population, especially in the adolescent population. Several scientific studies in the literature focused on swimming, its effects and the relationship with injuries and deformities of the spine. Purpose: this brief review, in an attempt to answer this question, aims to compare several studies that have focused attention on the relationship between the possible appearance of postural problems and swimming activity practiced at a competitive level. Methods: a literature search was conducted for articles published between 2000 and 2020 with the exception of two pilot studies from the 1990s. The review was carried out in the following databases: Web of Science, PubMed, Scopus, Science Direct and Google Scholar. In addition, further studies were consulted by accessing specific journals. The search terms used were: swimming, electromyography, back-pain, muscles activity, scoliosis, and crawl. To select the studies, the following criteria were identified: use of electromyography as an investigation tool; sample of competitive swimmers aged between 12 and 17 years. Results: the results were summarized in a table indicating authors, year of publication, objective, sample, swimming style analysed, research methodology and specific results. The analysis of the literature generally shows the existence of a relationship between intensity of training and the occurrence and aggravation of dysmorphisms or paramorphisms. In addition, the selected studies show the importance assigned to core training in the prevention of postural imbalances.
\end{abstract}

Keywords: Swimming; Back pain; Electromyography; Posture; Adolescence.

\section{Cite this article as:}

D’Anna, C., D’Alessandro, A., \& Vastola, R. (2020). Swimming, back pain and electromyography: A brief review. Journal of Human Sport and Exercise, 15(4proc), S1187-S1194. doi:https://doi.org/10.14198/jhse.2020.15.Proc4.20

Corresponding author. Department of Human, Philosophical and Educational Sciences, University of Salerno, Italy. https://orcid.org/0000-0003-0216-0318

E-mail: cdanna@unisa.it

Abstract submitted to: Spring Conferences of Sports Science. Costa Blanca Sports Science Events, 19-20 June 2020. Alicante, Spain.

JOURNAL OF HUMAN SPORT \& EXERCISE ISSN 1988-5202

(c) Faculty of Education. University of Alicante

doi:10.14198/jhse.2020.15.Proc4.20 


\section{INTRODUCTION}

The low back is the most common site of pain in the population, especially in the adolescent population (Haus \& Micheli, 2012).

Several scientific studies in the literature focused on swimming, its effects and the relationship with injuries and deformities of the spine (Martens et al., 2015; Folkvardsen et al., 2016; Jones, 1999). For years the ability to correct the postural structure of those who practice it has been attributed to swimming, but the studies of the last fifty years have progressively denied this quality, highlighting how this statement cannot be subject to generalizations, but that situations must be analysed according to specific cases. This study arises from the need to understand whether swimming, practiced at a competitive level and with a certain workload, can affect the normal development of the structures and curves of the spine.

Research in this area began in the early 1900s, particularly in the service sector. Subsequently, the studies evolved and became more and more complex, touching on different aspects, going beyond the performance area alone and starting to approach the functional, physiological and sometimes clinical area.

The evolution of the studies is mainly to be associated with technological evolution which in this area plays a role of priority importance, as the development of increasingly sophisticated technologies has allowed progressively more detailed, accurate and safe observations.

In relation to the specific case of EMG, it is possible to note how not only observation and detection have become easier, but also how the various steps have allowed new fields of applications and greater speed, precision and reliability in the acquisition of data, especially as regards swimming, which certainly requires the preparation of a type of technology that is more developed than in other environments and situations.

The development of these studies has often raised debates related to the positive or negative effects of swimming, sometimes drawing generalizations that do not take into account the necessary distinctions to be placed at the basis of the observation: competition and amateurism, a factor that significantly affects the moment in which we intend to address the functional and physiological aspect.

\section{MATERIALS AND METHODS}

The literature analysis was mainly done using the following databases: Google Scholar, PubMed, Web of Science. In addition, further studies were consulted by accessing the following specific journals: "Journal of Electromyography and Kinesiology", "The Journal of Pediatric", "International journal of sports physiology and performance", "Journal of Sports Sciences".

The literature search was done using the following keywords: swimming, EMG, Back-pain, muscles activity, scoliosis, crawl.

Once the articles that corresponded to these lines were collected, a new criterion was used, so as to be able to highlight and select more and more accurately the articles and searches that comply with the lines described below.

1. Period. The articles and research carried out in the period from the 2000 s to today were selected, except for two studies from the last half of the $90 \mathrm{~s}$. The latter have been selected because they 
represent the pilot studies for the subsequent ones, which not only laid the foundations, but also provided what were the first insights in this direction.

2. Studies with EMG. The criterion subsequently applied concerns the choice of the EMG as an investigation tool. In fact, those articles were chosen that used it as the main tool, in what are its different forms and evolutions.

3. Age of the sample. Once the period of interest and the specific research area have been selected, another selection criterion has been added, in relation to the age of the participants in the observations. Studies were therefore selected that had subjects between the ages of 12 and 20 as participants, as they were considered the most sensitive to these changes.

4. Competitive athletes. A further selection criterion meant that the attention referred to studies in which the participants were agonists at national and international level, therefore effectively engaged in competitions on a regular basis and therefore subjected to a certain type of training. And this is precisely the last criterion used, that is, research that included athletes who respond to a total of hours of weekly training between 18 and 24 hours were taken into consideration. Some of them even with multiple training sessions per day. Finally, some of the selected articles present a control group consisting of non-competitive athletes, with the aim of recording whether the results achieved for individual cases were actually directly related to the competitive condition or not.

The analysis of the literature identified through the criteria was mainly aimed at identifying the objectives and results of these.

\section{RESULTS}

The summary table (Table 1) summarizes the results of the review, highlighting for each study selected in the literature: the intended objectives, the sample, the swimming styles under investigation, the research methodology used and the results. The analysis of the literature made it possible to relate the work of different scholars, who have experimented in different countries and years, but with the same intuition and often converging on the results obtained.

Table 1. Summary table.

\begin{tabular}{|c|c|c|c|c|c|}
\hline $\begin{array}{l}\text { Author } \\
\text { and Year }\end{array}$ & Target & Participants & $\begin{array}{l}\text { Swimming } \\
\text { Style }\end{array}$ & $\begin{array}{l}\text { Type } \\
\text { of EMG }\end{array}$ & Results \\
\hline $\begin{array}{l}\text { Ruwe } \\
\text { (1994) }\end{array}$ & $\begin{array}{l}\text { Study the activity of the } \\
\text { mainly effected muscles } \\
\text { during swimming in a } \\
\text { relation with all } \\
\text { swimming styles. The } \\
\text { analysis includes a } \\
\text { comparison between } \\
\text { swimmers with and } \\
\text { without Back-Pain. }\end{array}$ & $\begin{array}{l}25 \text { swimmers } \\
\text { without Back-Pain } \\
\text { and } 14 \text { swimmers } \\
\text { with Back-Pain }\end{array}$ & Breaststroke & $\begin{array}{l}\text { Telemetric } \\
\text { EMG }\end{array}$ & $\begin{array}{l}\text { In the swimmers } \\
\text { with Back-Pain } \\
\text { situation the } \\
\text { muscles activity is } \\
\text { irregular. These } \\
\text { situations caused an } \\
\text { opposite } \\
\text { compensation to the } \\
\text { pain. }\end{array}$ \\
\hline $\begin{array}{l}\text { Verni et al. } \\
\text { (1999) }\end{array}$ & $\begin{array}{l}\text { An investigation of spine } \\
\text { pain caused by } \\
\text { swimming. }\end{array}$ & $\begin{array}{l}14 \text { swimmers but } \\
\text { only } 7 \text { with spine } \\
\text { pain at the } \\
\text { beginning of the } \\
\text { study. }\end{array}$ & Crawl & EMGS & $\begin{array}{l}\text { Swimming } \\
\text { contributes to } \\
\text { accentuating spinal } \\
\text { deformity conditions, } \\
\text { if they aren't well } \\
\text { treated before } \\
\text { starting a } \\
\text { competitive activity. }\end{array}$ \\
\hline
\end{tabular}




\begin{tabular}{|c|c|c|c|c|c|}
\hline $\begin{array}{l}\text { Santana } \\
\text { (2005) }\end{array}$ & $\begin{array}{l}\text { Effect of Core training in } \\
\text { the competitive and not } \\
\text { competitive swimmers } \\
\text { training program. }\end{array}$ & $\begin{array}{l}\text { University of } \\
\text { Florida swimming } \\
\text { team composed } \\
\text { to } 24 \text { athletes. }\end{array}$ & All & EMGS & $\begin{array}{l}\text { The correct } \\
\text { stimulation of the } \\
\text { core muscles allows } \\
\text { a more precise and } \\
\text { stronger technical } \\
\text { gesture. }\end{array}$ \\
\hline $\begin{array}{l}\text { Caty } \\
(2007)\end{array}$ & $\begin{array}{l}\text { Study of stabilizer } \\
\text { muscles in freestyle } \\
\text { (crawl). }\end{array}$ & $\begin{array}{l}7 \text { male swimmers } \\
\text { that participate to } \\
\text { international } \\
\text { competitions in } \\
100 \text { Freestyle. } \\
\text { They are to } 20 \text { at } \\
22 \text { years old. }\end{array}$ & Crawl & $\begin{array}{l}\text { EMG fine } \\
\text { wire } \\
\text { telemetric }\end{array}$ & $\begin{array}{l}\text { The Core is one of } \\
\text { the main stabilizing } \\
\text { areas in Freestyle. }\end{array}$ \\
\hline $\begin{array}{l}\text { Knobloch et } \\
\text { al. (2008) }\end{array}$ & $\begin{array}{l}\text { Observation based on } \\
\text { the high presence of } \\
\text { injuries and Back-Pain in } \\
\text { swimmers that are } \\
\text { subject to high intense } \\
\text { training. }\end{array}$ & $\begin{array}{l}341 \text { elite } \\
\text { swimmers. They } \\
\text { are to } 11 \text { at } 19 \\
\text { years old. }\end{array}$ & $\begin{array}{l}\text { Crawl e } \\
\text { Butterfly }\end{array}$ & EMGS & $\begin{array}{l}\text { The athletes who } \\
\text { practice swimming } \\
\text { to high levels, have } \\
\text { the most risk of } \\
\text { developing Back- } \\
\text { Pain conditions } \\
\text { during the training if } \\
\text { they aren't well } \\
\text { observed too. }\end{array}$ \\
\hline $\begin{array}{l}\text { Angela } \\
\text { (2011) }\end{array}$ & $\begin{array}{l}\text { Analysis of Core training } \\
\text { in a relationship between } \\
\text { performance and Back- } \\
\text { Pain in swimming. }\end{array}$ & $\begin{array}{l}18 \text { athletes that } \\
\text { are observed in } \\
12 \text { weeks during } \\
\text { training. }\end{array}$ & $\begin{array}{l}\text { Crawl e } \\
\text { backstroke }\end{array}$ & EMGS & $\begin{array}{l}\text { If there is a good } \\
\text { level of strength } \\
\text { expressed by the } \\
\text { Core, is possible } \\
\text { prevents the risk of } \\
\text { accentuating } \\
\text { situation of spine } \\
\text { deformity and also it } \\
\text { contributes to an } \\
\text { improvement of } \\
\text { performance. }\end{array}$ \\
\hline $\begin{array}{l}\text { Wanivenhaus } \\
\text { et al. (2012) }\end{array}$ & $\begin{array}{l}\text { Study on swimmers that } \\
\text { have a predisposition to } \\
\text { develop pain and spine } \\
\text { deformities. }\end{array}$ & $\begin{array}{l}35 \text { members of } \\
\text { Canadian Olympic } \\
\text { team. }\end{array}$ & Crawl & EMG & $\begin{array}{l}\text { Subjects that have } \\
\text { slight postural } \\
\text { imbalances at the } \\
\text { beginning of the } \\
\text { sport activity are } \\
\text { more predisposed to } \\
\text { develop pain and } \\
\text { spine deformity. }\end{array}$ \\
\hline $\begin{array}{l}\text { Lauer } \\
\text { (2013) }\end{array}$ & $\begin{array}{l}\text { Application and } \\
\text { coactivation of the } \\
\text { muscles that are } \\
\text { examined during } \\
\text { Freestyle. It is based on } \\
\text { the different phases of } \\
\text { the technical gesture. }\end{array}$ & $\begin{array}{l}10 \text { athletes that } \\
\text { participate at } \\
\text { international } \\
\text { competitions in } \\
200 \text { Freestyle. } \\
\text { They are to } 19 \text { at } \\
22 \text { years old. }\end{array}$ & Crawl & $\begin{array}{l}\text { EMGS on- } \\
\text { line }\end{array}$ & $\begin{array}{l}\text { The surveys of the } \\
\text { muscles activity } \\
\text { during the technical } \\
\text { gesture in the } \\
\text { swimming, It } \\
\text { highlights how the } \\
\text { Core is also } \\
\text { stressed during the } \\
\text { process of dynamic } \\
\text { balance maintaining. }\end{array}$ \\
\hline
\end{tabular}




\begin{tabular}{|c|c|c|c|c|c|}
\hline $\begin{array}{l}\text { Zaina et al. } \\
\text { (2015) }\end{array}$ & $\begin{array}{l}\text { Comparison between } \\
\text { spine deformities and } \\
\text { Back-Pain. }\end{array}$ & $\begin{array}{l}112 \text { teens that } \\
\text { participate to } \\
\text { swimming } \\
\text { competitions and } \\
217 \text { students that } \\
\text { practice } \\
\text { swimming as a } \\
\text { free time activity. } \\
\text { They are } \\
\text { approximately } 13 \\
\text { years old. }\end{array}$ & Crawl & EMGS & $\begin{array}{l}\text { Swimming can } \\
\text { increase to arise } \\
\text { spinal deformities } \\
\text { and Back-Pain } \\
\text { conditions. }\end{array}$ \\
\hline $\begin{array}{l}\text { Martens et al. } \\
\text { (2015) }\end{array}$ & $\begin{array}{l}\text { Study with EMG to } \\
\text { analyse the most } \\
\text { stressed muscles in all } \\
\text { swimming styles. }\end{array}$ & $\begin{array}{l}200 \text { Athletes that } \\
\text { are divided in four } \\
\text { groups to } 50 \\
\text { swimmers. }\end{array}$ & $\begin{array}{l}\text { Crawl, } \\
\text { breaststroke, } \\
\text { butterfly e } \\
\text { backstroke }\end{array}$ & EMGS & $\begin{array}{l}\text { The muscles that } \\
\text { most influence the } \\
\text { Postural and } \\
\text { functional aspects } \\
\text { are the muscles } \\
\text { stressed in freestyle } \\
\text { and butterfly style. }\end{array}$ \\
\hline $\begin{array}{l}\text { Parvis et al. } \\
(2016)\end{array}$ & $\begin{array}{l}\text { A study on diseases, } \\
\text { injuries and spine } \\
\text { curvatures after } \\
\text { swimming rehabilitation. } \\
\text { The study focuses the } \\
\text { attention also on } \\
\text { frequency with which } \\
\text { these conditions may } \\
\text { arise. Moreover, } \\
\text { observed the } \\
\text { relationship between the } \\
\text { intensity of movement } \\
\text { and the situation of } \\
\text { Back-Pain during the } \\
\text { sporting season. }\end{array}$ & $\begin{array}{l}27 \text { competitive } \\
\text { swimmers that } \\
\text { participate to } \\
\text { international and } \\
\text { national } \\
\text { competitions. }\end{array}$ & Crawl & EMG & $\begin{array}{l}\text { The research shows } \\
\text { how intense } \\
\text { swimming training } \\
\text { and activity. } \\
\text { Especially after } \\
\text { rehabilitation } \\
\text { periods, increases } \\
\text { the possibility to } \\
\text { develop an irregular } \\
\text { accentuation of } \\
\text { physiological curves. }\end{array}$ \\
\hline
\end{tabular}

\section{DISCUSSION}

Each article has been read and studied to understand not only what the research activity was, but above all the methodology, dynamics and context that characterized them. The choice to include articles prior to the selected period, in fact, was dictated by the desire to understand what were the bases and the starting points that gave rise to such an interest in research in this area. In fact, it has been noted that the intuition of these articles has not proved wrong, despite the underdeveloped technologies, but on the contrary, subsequent studies have corroborated the thesis already expressed, enriching it with further elements, which have proved necessary for the understanding of these aspects. The analysis started from what was a common belief, namely that swimming activity was a complete activity, but this vision soon became more and more characterized by elements that do not completely deny this perspective but do not even confirm it completely. In fact, it is not wrong to define swimming as a complete sport, but in this perspective, aspects such as the natural asymmetry deriving from the spontaneous dominance of one side of the body must be considered, which generates a different tone between the two parts and consequently generates different thrusts that affect not only muscle development but also on the technical gesture that in the long run can, if excessively stressed, weigh on any imbalances already present at a structural level. The analysis also highlighted the need for a careful medical history for each individual athlete not only in relation to research, but to be extended 
to the entire process followed by competitive athletes. Furthermore, once the common elements of the various studies have been collected, which have given rise to reflections such as the one just exposed, these have been compared to detect any discordant elements. Once this study and comparison work has been done, the collected data have been included in the table that represents the brief review of this work. The first articles analysed in this study refers to the works of Ruwe (1994) and Verni et al. (1999). Ruwe dedicates his attention to a study that focuses on an observation aimed at which muscles are mainly involved in the various swimming styles, taking two groups of swimmers as a study sample. The first group consisted of swimmers who did not have back-pain conditions, the second group did. It is the first study in which we can observe the presence of a control group, a need also linked to the need to identify whether the back-pain conditions can actually be generalized to both groups or understand how often these conditions affect the activities of one group or the other. In Ruwe's case, the study was carried out mainly in relation to the back style, and the measurements obtained with the EMG methodology showed how in the case of back-pain situations (therefore in the case of the second group) the activation of the muscles is irregular and it tends towards an opposite compensation to pain, this inevitably leads to an asymmetrical development of movement and structures, aggravating what were the starting conditions. In fact, it was one of the first articles to disprove what was considered the "corrective power" of swimming. As regards the study carried out by Verni et al. (1999) an investigation was carried out on the pains in the spine resulting from swimming. This study was carried out in collaboration with Comitato Olimpico Nazionale Italiano (CONI), and in this case, we are faced with an observation with a control group. Swimmers with spinal deformities (scoliosis, hyper kyphosis and hyperlordosis) were selected, while none of the participants found similar conditions in the second group. Also, in this study, the methodology used to understand the movement of muscles in relation to their action on the spine is the EMG. The study was able to affirm that swimming contributes to accentuate the conditions of spinal deformity, which the first group had already from the beginning of the study, in particular if these are not well treated before the start of the competitive activity, integrating with others types of work involving postural correction. With the analysis more and more accurate and evolved with respect to the studies just illustrated, Santana (2005), carries out a research on what are the muscles that apparently do not seem involved in swimming activity, focusing her attention on the role played by the core in the technical gesture. Santana, for his study will use the EMGS which will allow him to affirm, even after careful observation also addressed to the training programs, that the correct stimulation of the core muscles allows a more precise and stronger technical gesture. This will be responsible for controlling and adjusting the position, so that the athlete has less effort in finding the correct balance and therefore being able to use more energy in the stroke and kick. It is precisely in relation to the concept of stability that we find the study analysed later, carried out by Caty in 2007. His study focuses on the observation of the movement stabilizer muscles regarding the crawl. The athletes who took part in the study specialize in $100 \mathrm{M}$ freestyle and are more involved in international competitions. The observation in this case was carried out with telemetry EMG and has highlighted once again the central role of the Core in the process of stability of the movement. This concept is fundamental in particular at high levels. The study published in 2011 by Angela, which through the use of the EMGS, monitors the activity of the Core, put it in relation to cases of back-pain and observing it at the same time under the aspect of high performance level. In fact, at the end of her study, Angela affirms that what can be defined as a good level of strength, expressed by the Core, contributes to the prevention of the risk of accentuating situations of spinal deformity and at the same time contributes to an increase in the level of performance. The main reference article for what was the literature search is the one published by Jonas Martens et al. in the Journal of Electromyography and Kinesiology (2015). This article aims to collect the most relevant studies within the four swimming styles of the last fifty years. The study focused on the observation of the muscles most involved in the four styles, and on those that interact directly on the deformities of the spine. In the same article there is a review that collects not only all the most relevant studies in this area but collects all the most cutting-edge articles for each period. The authors, as well as thanks to 
their own observations, but also supported by the collection and analysis of previous studies, agree that the muscles that most influence the postural and functional aspect are identifiable with those stressed mostly in freestyle and in the butterfly style. Furthermore, within the research, it is highlighted how intense swimming sporting activity, in particular after periods of rehabilitation, increases the risk of an irregular accentuation of the physiological curves, an aspect in common with the most recent article of the review of this study (Parvis et al. 2016). Based on what has been stated so far, we can therefore conclude by stating that there is indeed a significant relationship between all the structures of our body, as regards the role played by muscle chains and the Core, in swimming. This performs various functions including support, protection and antagonist of the spinal column; it is also responsible for the adjustment function as regards movement, it is a source of stability and strength. From the analysis of the literature it also emerged that as regards the deformities of the spine, the onset cannot be traced back to swimming, but the same thing cannot be said for the accentuation of any pre-existing conditions. This is the reason why integration with real forms of corrective exercise, external to swimming, is recommended. Finally, the way in which the activity is approached and practiced is one of the pillars of the investigation. In fact, it emerged that swimming practiced at a competitive level, given the prolonged times and the intensity of training, favours possible injuries such as the consumption of cartilage and the possibility, in the long run, of favouring back-pain conditions.

\section{CONCLUSION}

The use of electromyography, as an investigation tool to analyse the activation of the various muscles involved in the sporting gesture of swimming, brings together all the scientific studies selected in this review, that compared several studies that have focused attention on the relationship between the possible appearance of postural problems and swimming activity practiced at a competitive level in agonist adolescents that are between 12 to 20 years old.

From this brief review emerged a series of reflections:

- The analysis of the literature generally shows the existence of a relationship between training intensity and the occurrence and aggravation of dysmorphisms or paramorphisms.

- More studies that are selected show the importance of core training in the prevention to postural imbalances. The review shows that over the years (from the 90 s to today) the concept of training has changed considerably about swimming programs; in fact, it emerges that the most recent workouts have as a priority objective the development of functional structures that do not have negative consequences on posture in general and on the daily life of athletes.

- The aspect of prevention of postural imbalances is more and more central to the design of competitive level training.

In conclusion, the analysis of the literature provides the necessary data to understand how the general activation of the muscles, in particular of the core, in swimming, favours the improvement of the performance level, both by activating a preventive action towards the maintenance of physiological curves of the spine which reducing the risk of developing any pathological situations or backpain.

Certainly, the present study is not without its critical points. It would be interesting to look at other studies that use different investigation tools such as kinematic analysis with inertial sensors or video analysis. Considering the evidence that emerged, it is proposed to carry out a biomechanical study of the four swimming styles in elite athletes through an integrated approach. 


\section{REFERENCES}

Angela, E., 2011. Development and evaluation of a core training programme in highly trained swimmers. $\mathrm{PhD}$ Thesis. Teesside University.

Caty, V., Aujouannet, Y., Hintzy, F., Bonifazi, M., Clarys, J.P. \& Rouard, A.H. 2007. Wrist stabilisation and forearm muscle coactivation during freestyle swimming. In Journal Electromyogr Kinesiol;17:285-91. https://doi.org/10.1016/i.jelekin.2006.02.005

Folkvardsen, S., Magnussen, E., Karppinen, J., Auvinen, J., Larsen, R. H., Wong, C., \& Bendix, T. 2016. Does elite swimming accelerate lumbar intervertebral disc degeneration and increase low back pain? A cross-sectional comparison. In European Spine Journal, 25(9), 2849-2855. https://doi.org/10.1007/s00586-016-4642-x

Haus, B.M. \& Micheli, L.J. 2012. Back pain in the pediatric and adolescent athlete. In Clin Sports Med. 2012 Jul;31(3):423-40. Epub 2012 May 3. https://doi.org/10.1016/i.csm.2012.03.011

Jones, J. H. 1999. Swimming overuse injuries. In Physical Medicine and Rehabilitation Clinics, 10(1), $77-$ 94. https://doi.org/10.1016/S1047-9651(18)30217-1

Knobloch, K., Yoon, U., Kraemer, R., \& Vogt, P. M. 2008. 200-400 m breaststroke event dominate among knee overuse injuries in elite swimming athletes. Sportverletzung Sportschaden: Organ der Gesellschaft fur Orthopadisch-Traumatologische Sportmedizin, 22(4), 213-219. https://doi.org/10.1055/s-2008-1027987

Lauer, J., Figueiredo., P., Vilas-Boas, J.P., Fernandes, R.J. \& Rouard, A.H. 2013. Phase-dependence of elbow muscle coactivation in front crawl swimming. Journal Electromyogr Kinesiol 2013;23:820-5. https://doi.org/10.1016/i.jelekin.2013.02.004

Martens, J., Figueiredo, P.D. \& Daly, D. 2015. Electromyography in the four competitive swimming strokes: A systematic review. In Journal of Electromyography and Kinesiology, Volume 25, Issue 2, April 2015, Pages 273-291. https://doi.org/10.1016/i.jelekin.2014.12.003

Parvis, V., Grassini, S., Angelini, E. \& Scattareggia, P. 2016. Swimming symmetry assessment via multiple inertial measurements, 2016 IEEE International Symposium on Medical Measurements and Applications (MeMeA), Benevento, 1-6. https://doi.org/10.1109/MeMeA.2016.7533765

Ruwe., P.A., Pink, M., Jobe, F.W., Perry, J. \& Scovazzo, M.L. 1994. The normal and the painful shoulders during the breaststroke: electromyographic and cinematographic analysis of twelve muscles. Am J Sports Med. 1994;22(6):789-796. https://doi.org/10.1177/036354659402200610

Santana, J. C. 2003. The serape effect: A kinesiological model for core training. Strength \& Conditioning Journal, 2003, 25.2: 73-74. https://doi.org/10.1519/00126548-200304000-00013

Verni, E., Prosperi, L., Lucaccini, C., \& Fedele, L. 1999. Lumbar pain and fin swimming. In Journal of sports medicine and physical fitness, 39(1), 61.

Wanivenhaus F, Fox AJ, Chaudhury S, Rodeo SA. 2012. Epidemiology of injuries and prevention strategies in competitive swimmers. Sports Health, 4(3):246-251. https://doi.org/10.1177/1941738112442132

Zaina, F., Donzelli, S., Lusini, M., Minnella, S. \& Negrini, S. 2015. Swimming and Spinal Deformities: A Cross-Sectional Study. In The Journal of pediatrics, 166(1), 163-167. https://doi.org/10.1016/i.jpeds.2014.09.024

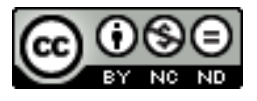

This work is licensed under a Attribution-NonCommercial-NoDerivatives 4.0 International (CC BY-NC-ND 4.0). 